CURSO DE ESPECIALIZAÇÃO EM DESENVOLVIMENTO HUMANO, EDUCAÇÃO E INCLUSÃO ESCOLAR - UAB/UnB

\title{
AVALIAÇÃO DOS ALUNOS COM NECESSIDADES EDUCACIONAIS ESPECIAIS NAS SÉRIES INICIAIS
}

\author{
CÍNTIA ROCHA RIBEIRO DAMACENA
}

ORIENTADORA: CLEIA ALVES NOGUEIRA

BRASÍLIA/2011 


\section{AVALIAÇÃO DOS ALUNOS COM NECESSIDADES EDUCACIONAIS ESPECIAIS NAS SÉRIES INICIAIS}

Monografia apresentada ao Curso de Especialização em

Desenvolvimento Humano, Educação e Inclusão, da Faculdade UAB/UNB - Pólo de Formosa/GO.

Orientadora: Professor Cleia Alves Nogueira

BRASÍLIA/2011 


\title{
AVALIAÇÃO DOS ALUNOS COM NECESSIDADES EDUCACIONAIS ESPECIAIS NAS SÉRIES INICIAIS
}

\begin{abstract}
Monografia aprovada como requisito parcial para obtenção do grau de Especialista do Curso de Especialização em Desenvolvimento Humano, Educação e Inclusão Escolar - UAB/UnB. Apresentação ocorrida em /2011. Aprovada pela banca formada pelos professores:
\end{abstract}

CLEIA ALVES NOGUEIRA (Orientadora)

GABRIELA SOUSA MELO MIETO (Examinador)

CÍNTIA ROCHA RIBEIRO DAMACENA (Cursista)

BRASÍLIA/2011 


\section{DEDICATÓRIA}

Aos meus pais João Gilson e Maria da Conceição, que sempre fizeram o melhor que podiam para meu crescimento pessoal e profissional e vejo que se orgulham ao me verem cumprir com mais uma etapa na vida. 


\section{AGRADECIMENTOS}

Agradeço a Deus por mais esta conquista em minha vida, pela oportunidade de crescimento profissional e realização pessoal. Ao meu marido Marcelo que me incentivou e junto com meus filhos respeitaram a minha dedicação. A minha orientadora Cleia Alves Nogueira, que, com sua paciência e profissionalismo compartilhou com o desenvolvimento desse trabalho. 


\section{RESUMO}

A Instituição de Ensino desenvolvendo a função social de atender às diversidades sociais, educacionais e cognitivas, vem se preparando a cada dia para atender aos Alunos com Necessidades Educacionais Especiais (ANEE), para a inclusão. A evolução do atendimento da educação especial no mundo e no Brasil, nos dá uma visão muito clara do quanto se desenvolveu este apoio nesses últimos tempos. Este estudo teve como objetivo analisar o desempenho desses alunos para melhor compreensão dos processos avaliativos da inclusão no Ensino Fundamental. No caso específico deste trabalho, pesquisei o rendimento dos alunos com necessidades educacionais especiais, baseada numa perspectiva qualitativa considerando as estratégias, os procedimentos, os instrumentos de avaliação e as adequações curriculares. A partir das entrevistas realizadas com alguns pais do ANEE e questionário com professores e equipe gestora da Unidade de Ensino pesquisada, busquei analisar a proposta pedagógica para com base nos resultados encontrados dar razão a um aprofundamento teórico dentro das necessidades específicas do tema. Para que esse processo ocorra de forma eficaz, fez-se necessário a busca da psicopedagogia, para o atendimento aos alunos e para a dinâmica dentro da escola promovendo a avaliação e intervenção. O objetivo é uma harmonia entre a teoria, a prática escolar e a sociedade que nos cerca a fim de um diálogo humanizado dos procedimentos avaliativos; de avaliação formativa e processual buscada nesta pesquisa. Resultando no seguinte: equipe gestora, o Projeto Político Pedagógico e professores buscam utilização de uma avaliação processual e formativa, mas na prática estão apegados em semana de provas, desconsiderando como os pais que acreditam apenas em provas e notas para certificação do aprendizado dos filhos; necessitando de um novo olhar sobre essa prática.

Palavras chave: Inclusão. Avaliação. Ensino fundamental. 


\section{SUMÁRIO}

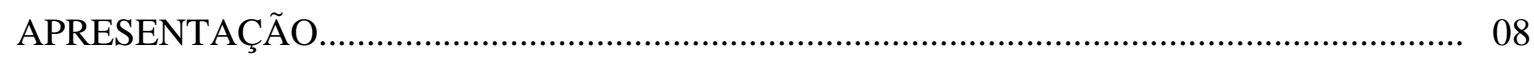

I - FUNDAMENTAÇÃO TEÓRICA................................................................................. 11

1.1 - DIFERENTES OLHARES SOBRE A AVALIAÇÃO NA INCLUSÃO...........................12

1.2 - AVALIAÇÃO DA APRENDIZAGEM NUMA PERSPECTIVA INCLUSIVA.................13

1.3 - A DIVERSIDADE NA ESCOLA.............................................................................. 14

1.4 - RECONHECER AS ESTRATÉGIAS DA AVALIAÇÃO................................................. 15

1.5 - ADEQUAÇÕES CURRICULARES NECESSÁRIAS ....................................................... 16

1.6 - PROCEDIMENTOS DE AVALIAÇÃO DA APRENDIZAGEM USADOS EM SALA

DE AULA.......................................................................................... 17

1.6.1 - AVALIAÇÃO E PROMOÇÃO................................................................................. 17

1.7 - ALGUMAS PRÁTICAS COTIDIANAS DE ATUAÇÃO DE EQUIPES

MULTIDISCIPLINARES E INTERDISCIPLINARES NA AVALIAÇÃO E ACOMPANHAMENTO DOS ANEE............................................................................... 19

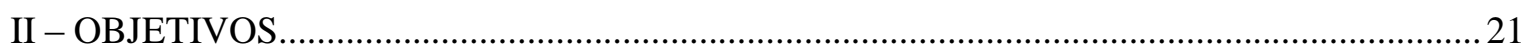

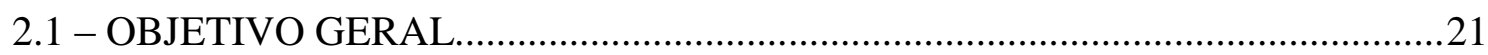

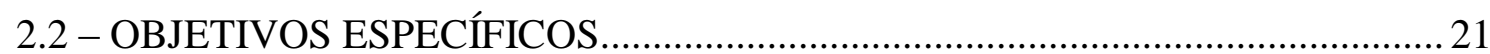

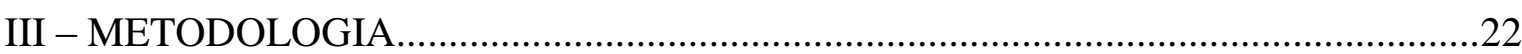

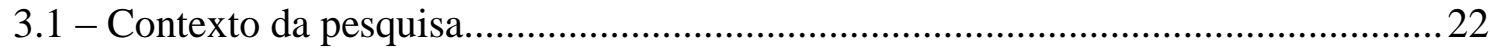

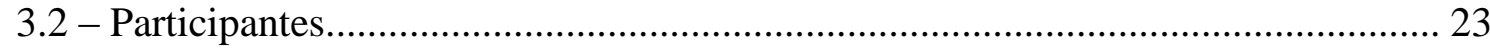

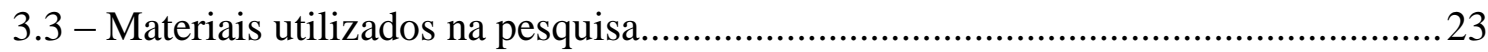

3.4 - Instrumentos de construção de dados.....................................................................24

3.5 - Procedimentos de construção de dados....................................................................... 24

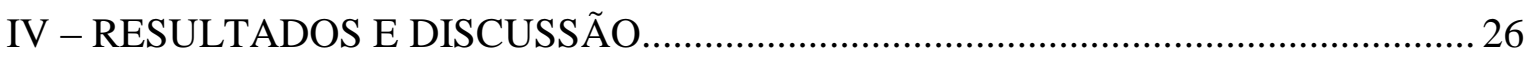

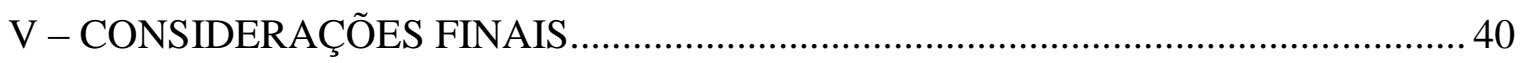

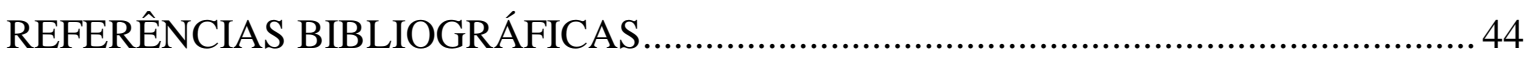

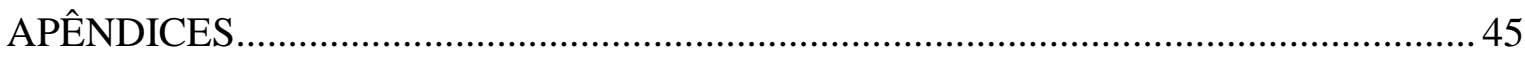

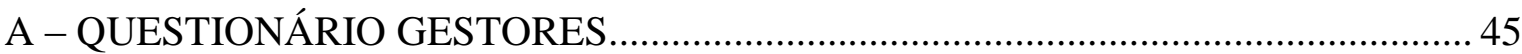

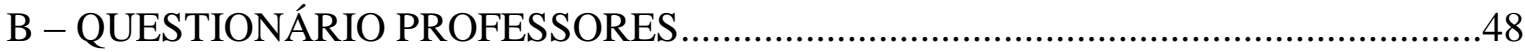

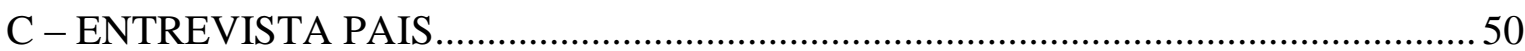

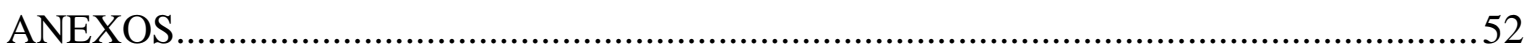

A - Carta de Apresentação............................................................................................... 52

B - Termo de Consentimento Livre e Esclarecido - Professor............................................ 54 


\section{APRESENTAÇÃO}

Atuando como professora dos Alunos com Necessidades Educacionais Especiais (ANEE), vejo o quanto não fui preparada, assim como os demais professores desta Unidade de Ensino para trabalhar com este público: e passa a se agravar mais esta situação quando se pensa em avaliação dos mesmos, pois avaliar como, o quê, para quê, se não se tem certeza nem do que foi trabalhado.

Descrevo esta vivência logo no início desta apresentação, confirmando o fato que me trouxe a esta especialização, assim como a outros cursos para sanar minhas angústias a respeito desta inclusão que nos pegou "de calças curtas" e veio para ficar, desencorajando ou amedrontando muitos professores, levando-nos ao sentimento de incompetência profissional.

Em resgate da minha vida escolar, não me lembro de ter contato com nenhum colega com necessidade educacional especial na escola e muito pouco nas ruas. Estas pessoas viviam marginalizadas, escondidas em suas casas, pois os pais não viam como possível o desenvolvimento e interação social dos mesmos.

Logo que comecei o curso de magistério, estudei várias didáticas, fiz muitos estágios, mas nenhum que refletisse sobre o desenvolvimento dos ANEE, pois até então eles eram mantidos em casa, ou na melhor das hipóteses eles chegavam aos Centros de Ensino Especial e lá ficavam até a vida adulta.

Agora que nestes últimos anos é que vem acontecendo a inclusão para profissionais como eu que nunca vivi, estudei ou escolhi me aperfeiçoar no assunto que até então fez-se desnecessário à minha realidade.

Atualmente a escola abre as portas aos alunos com necessidades educacionais especiais, desenvolvendo várias funções que vão além de apenas transmitir conhecimentos, devendo trabalhar a socialização e cooperação para se ampliar o entendimento da diversidade presente em nossa realidade.

É fato o aumento das matrículas dos ANEE na rede pública de ensino e, com isso, o centro das atenções governamentais passou a ser a inclusão e juntamente a garantia da qualidade do ensino, visto que os resultados da aprendizagem destes alunos estão no nível abaixo do esperado. Não sei se por dificuldade de aprendizagem, por falta de mais preparo dos professores, falta estrutura física, falta de recursos humanos de apoio, didáticos, e 
tecnológicos com capacidade de oferecer o atendimento ao ANEE, dificultando o desenvolvimento desses alunos e a conseqüentemente levando-os ao fracasso.

A qualidade do processo ensino-aprendizagem aumenta quando a avaliação é também como instrumento de ensino, utilizada de forma planejada e organizada. É necessário que este instrumento seja adequado a objetivos que contemplam suas dificuldades/limitações destes alunos, de maneira a proporcionar um momento de troca e aprendizagem. Para isto analisaremos diferentes olhares sobre a avaliação na inclusão, reconhecendo as estratégias da avaliação e a percepção dos professores sobre a influência dos procedimentos da avaliação de aprendizagem.

O sistema tradicional de avaliação força uma relação oposta entre professor e aluno, impedindo sua cooperação,uma vez que a avaliação só tem o objetivo de quantificar o quanto se aprende e consequentemente classificar quem errou ou acertou, punindo aquele que não conseguiu o "certo" naquele momento. Diante deste fato fez-se necessário pesquisar a avaliação do ANEE nas séries iniciais de uma escola pública de Planaltina-DF, levando o leitor a refletir sobre a necessidade de aprender a interpretar processos contínuos de ensinoaprendizagem do ANEE para que assim ele possa ser avaliado de forma produtiva e contínua, contribuindo de forma significativa para sua inclusão e progresso no processo ensinoaprendizagem.

Para atender aos interesses descritos acima realizei uma pesquisa numa escola pública de Planaltina D.F. com pais, professores e equipe gestora de ANEE em séries iniciais. Os instrumentos de pesquisa utilizados foram questionários para gestores e professores, entrevistas para pais e análise da Proposta Pedagógica da escola com foco nos processos avaliativos sugeridos para desenvolvimento do planejamento pedagógico.

O estudo aqui apresentado foi refletido em uma base teórica, análises das pesquisas de campo, dados obtidos na investigação e nas estratégias de ensino-aprendizagem; na busca de uma nova maneira de avaliar o ANEE.

O trabalho buscou analisar diferentes olhares sobre a avaliação na inclusão, reconheceu as estratégias da avaliação, procedimentos da avaliação da aprendizagem usados em sala de aula e a percepção dos professores sobre a influência dos procedimentos da avaliação de aprendizagem.

Ao desenvolver seu processo de ensino, nós professores devemos manter alguns cuidados necessários com a avaliação da aprendizagem escolar. A avaliação deverá compreender a função do educando e a do educador, deixar claro que os resultados alcançados 
pelos alunos também avaliam a maneira que o professor passou o conteúdo para o aluno. $\mathrm{O}$ professor deverá buscar resultados satisfatórios de aprendizagem e caso isso não ocorra modificar seus planejamentos para encontrar maneira de conquistar o sucesso na aprendizagem. 


\section{I - FUNDAMENTAÇÃO TEÓRICA}

O projeto procurou analisar diferentes olhares sobre a avaliação na inclusão; primeiramente pretende-se salientar que a aprendizagem não é mais um processo de aquisição de conhecimentos, conteúdos ou informações. As informações são necessárias, mas devem ser significativas aos alunos. O objetivo é uma harmonia entre a teoria, a prática escolar e a sociedade que nos cerca a fim de um diálogo humanizado dos procedimentos avaliativos.

A diversidade na escola para se efetivar, deve romper com a concepção homogeneizadora do ensino, adotar uma flexibilização do conteúdo curricular e o modo como o currículo é incorporado à atividade escolar.

Ter ciência de que por meio dos instrumentos de avaliação da aprendizagem, estamos solicitando ao educando que manifeste a sua intimidade, seu modo de aprender, sua aprendizagem, sua capacidade de raciocinar, de poetizar, de criar estórias, seu modo de entender e de viver. (CIPRIANO, 2008, p. 177)

O desafio é reconhecer estratégias da avaliação que respondam à questão do acesso e da permanência do ANEE nas instituições educacionais, pois a inclusão não pode mais ser ignorada. No entanto, propõe-se elaborar estratégias considerando as condições dos alunos em relação aos demais colegas.

No dia em que a avaliação ensinada for compreendida como fonte de aprendizagem, e não só de resultados de aprendizagem, grande parte dos problemas de repetência, evasão, fracasso escolar, estarão resolvidos, pois o sujeito estará envolvido no seu processo de avaliação. (MEDIA-NO, 1999, p. 53)

Buscar um consenso quanto à compreensão de que a aprendizagem mais importante vai além daquela aquisição de informações, podendo ser usados diferentes procedimentos da avaliação; aquelas que ocorrem durante todo o processo ensino-aprendizagem e utilizar algumas práticas cotidianas de atuação das equipes multidisciplinares e interdisciplinares na avaliação e acompanhamento do ANEE.

A prática avaliativa concebida como julgamento de resultados baseia-se na autoridade e no respeito. Impõe-se aos alunos imperativos categóricos que limitam o desenvolvimento de sua autonomia intelectual e moral. Essa prática desconsidera a importância da reciprocidade na ação educativa. Reciprocidade entendida como uma mútua coordenação dos pontos de vista e das ações. (Piaget, Apud Hoffman, 2003, p.29) 
Podendo assim analisar que quando se fala em avaliação são inúmeras técnicas e métodos relacionados a ela, mas para realizar com responsabilidade é necessária a percepção dos professores sobre a influência dos procedimentos da avaliação de aprendizagem.

Sendo possível abordar técnicas avaliativas trabalhadas com consciência, reconhecendo ao que se dá mais importância no processo avaliativo, se à transmissão ou à compreensão, se ao ensino ou à aprendizagem, abrindo assim uma reflexão às inovações no cenário educacional onde se observa que o sucesso da aprendizagem está em explorar talentos, atualizar possibilidades, desenvolver predisposições naturais de cada aluno.

Pensar em avaliação é motivo de preocupação para pais, alunos e professores, então se faz necessária pensar como fonte de satisfação pessoal, busca da melhor adequação aos alunos e inclusão eficiente.

Esta análise mostra a insuficiência da prática da avaliação instituída para responder à dinâmica do processo ensino-aprendizagem e a necessidade de reconstrução dos métodos para avaliar como parte de um movimento articulado pelo compromisso com o desenvolvimento de uma prática pedagógica. Prática comprometida com a inclusão, com a pluralidade, com o respeito às diferenças, com a construção coletiva. Um movimento direcionado pela concepção da escola como território múltiplo, marcado pela diversidade de culturas e vozes. Esta transformação requer uma redefinição de vários critérios e paradigmas. (BARRIGA, 1999, p.98)

\section{1 - DIFERENTES OLHARES SOBRE A AVALIAÇÃO NA INCLUSÃO}

Primeiramente venho lembrar que a avaliação não é mera repetição de informações ou conteúdos. As informações tornam-se importantes quando significativas para as pessoas.

Portanto, a avaliação envolve as nossas vidas; Seja no campo emocional, social ou no desenvolvimento da nossa personalidade.

Com a avaliação procura-se identificar, conferir, investigar e analisar o rendimento e as modificações de comportamento do aluno, do educador, averiguando se houve a construção do conhecimento.

O uso tradicionalmente padronizado da avaliação cria "rótulos" e bloqueia outras visões de crescimento. Para Arroyo (In HOFFMAN, 2005, p., 18), quanto mais se degradam às condições sociais dos setores populares, mais seletiva se torna a escola, mais difícil se torna 
a infância e a adolescência acompanhar o elitismo de seus processos excludentes. Ficam os estudantes pobres cada vez mais expostos aos preconceitos que legitimam o fracasso escolar:

Pesquisas já têm mostrado que a cultura escolar estigmatiza e os rotula como diferentes, incapazes, inferiores, menos-dotados para o domínio das habilidades pretendidas e exigidas pelo processo ensino-aprendizagem. (HOFFMAN, 2005, p.49)

Sensibilidade, humanidade e cooperação são essenciais atitudes para desenvolver o respeito às diferenças. Porque os alunos deficientes são considerados incapazes? Como elaborar novos conceitos sobre as diferenças?

As práticas avaliativas primam por desrespeitar as diferenças e a individualidade dos alunos, em todas as áreas do desenvolvimento: social, intelectual, física e moral. Muitas vezes na escola, já se rotula o diferente. Buscam o padrão dito normal, homogeneidade.

Adotando critérios comparativos para o domínio de conhecimentos, o professor assume uma postura que resulta em descrições classificatórias de desempenho. Gardner ( In HOFFMAN, 2005, p. 19) salienta que se persegue incansavelmente "o igual" na escola e todas as diferenças são obstáculos impeditivos de aprendizagem: os alunos agitados ou muito quietos, os alunos pobres, doentes, de idade diversa, com talentos inesperados, com deficiências físicas e mentais, que falam outra língua...De tal forma o olhar do professor procura por desvios ao padrão determinados a priori que poucos sobrevivem à fúria avassaladora da comparação, resultando na perversidade de uma escola seletiva.

\section{2 - AVALIAÇÃO DA APRENDIZAGEM NA PERSPECTIVA INCLUSIVA}

Segundo Moantoan (2008, p. 11) os alunos, na perspectiva de uma escola para todos, não se reduzem a pessoas rotuladas por professores, ou por especialistas, que os condenam a categorizações e hierarquizações, impostas por aparatos psicológicos e pedagógicos (testes, provas, coeficientes, padrões de desenvolvimento, de desempenho acadêmico, entre outros).

Todo aluno é único, que precisa de estímulos para que se desenvolva significativamente em todos os aspectos, seja ele intelectual, pessoal ou social que vai progredindo de acordo com sua idade.

\section{3 - A DIVERSIDADE NA ESCOLA}


A escola é conhecida por adotar processos seletivos que tem como base a concepção homogeneizadora do ensino, construindo rótulos para os estudantes. O aluno que não se adéqua a esta padronização, é levado à evasão e ao fracasso escolar. Muitas vezes o aluno rotulado logo é encaminhado à especialista de áreas distintas para receber atendimento especializado.

Para se tornar possível as oportunidades é preciso que o sistema crie reforma na escola, em que haja flexibilização do conteúdo curricular e estratégias pedagógicas adaptadas às necessidades do aluno.

Uma escola inclusiva, não deve exaltar as situações de deficiência dos alunos, e sim adotar estruturas físicas e pedagógicas que minimize as dificuldades, tornando o currículo acessível e uma educação significativa.

Para atuar em uma educação inclusiva, algumas atitudes básicas devemos adotar: relevância às diferenças culturais individuais, sociais e culturais; adequar os processos de ensino aprendizagem; respeito à aceitação das diferenças numa sociedade plural e democrática.

Uma das tarefas é identificar constantemente as intervenções e as ações desencadeadas e/ou aprimoradas para que a escola seja um espaço de aprendizagem para todos os alunos. Isso exigirá novas elaborações no âmbito dos projetos escolares, visando ao aprimoramento de sua proposta pedagógica dos procedimentos avaliativos institucionais e da aprendizagem dos alunos. (MOANTOAN, 2006, p. 36).

As estratégias de aprendizagem, os procedimentos, os meios de acesso ao conhecimento e à informação bem como os instrumentos de avaliação devem ser adequados dos educando. Embora já tenhamos caminhado bastante na direção de uma escola inclusiva para todos, há muitas barreiras a serem transpostas. Cada vez mais percebemos que temos de aprender de novo a pensar sobre inclusão e a rever nossas práticas educativas, ainda que para isso seja necessário abandonar a segurança de nossos saberes, dos métodos e das linguagens que já possuímos, mas que também nos possuem. (MOANTOAN, 2008, p. 113).

(...) uma avaliação dinâmica interativa, que inclui o ensino durante o processo de avaliação. Caracteriza por um conjunto de estratégias institucionais utilizadas 
durante o processo de avaliação, a fim de garantir o fornecimento de ajuda, melhorando as condições da situação de avaliação, para que o examinando possa revelar o seu desempenho potencial e possa atingir um grau crescente de autonomia em situações de resolução de problemas (LINHARES, in. KELMAN, 2008, p. 17).

\section{4 - RECONHECER AS ESTRATÉGIAS DA AVALIAÇÃO}

Falar hoje em dia sobre inclusão, as instituições escolares tem o desafio de encontrar estratégias para o acesso e permanência deste público com adequações necessárias. Muitas escolas públicas e particulares vêm buscando mudanças na sua organização pedagógica, que reconheça e valorize as diferenças sem discriminação.

A inclusão não pode ser mais ignorada, podemos iniciar identificando permanentemente intervenções e ações para que a escola seja um espaço que valorize a todos os alunos em suas diferenças. Isso acarretará novas metas para proposta pedagógica da escola, dos procedimentos avaliativos bem como da aprendizagem dos alunos.

Outra tarefa é promover um entrosamento afetuoso entre alunos e professores, além de formação aos profisssionais da educação, para que venham ser co-responsáveis desse processo na inclusão dos alunos.

Vale ressaltar que a inclusão não é apenas manter os alunos com necessidades especiais na escola, mas promover a socialização e o respeito em todos os aspectos.

Ao contrário, implica uma reorganização do sistema educacional, o que acarreta a revisão de antigas concepções e paradigmas educacionais na busca de se possibilitar o desenvolvimento cognitivo, cultural e social desses alunos, respeitando suas diferenças e atendendo às suas necessidades. (GLAT e NOGUEIRA in MOANTOAN, 2006, p. 42).

No que diz respeito à educação especial, os estudos mais recentes enfatizam que as classificações atribuídas as deficiências, devem ser contextualizadas, não se prendendo a meras especificações, transtorno, distúrbio, síndrome ou aptidão. Consiste em considerar que as pessoas se modificam continuamente, se transformam de acordo com o contexto que está inserido. Essas mudanças exigem atuações pedagógicas distintas, voltadas a alterar situações de exclusão, implicando na importância dos ambientes heterogêneos para efetivação da aprendizagem significativa de todos os alunos.

A avaliação pedagógica como processo dinâmico consiste em levar em conta tanto o conhecimento prévio e as habilidades atuais do desenvolvimento dos alunos como as possibilidades de aprendizagem, utilizando de ação pedagógica processual e formativa que 
analisa o desempenho do aluno em relação ao seu processo individual, constando na avaliação características qualitativas que indiquem as intervenções pedagógicas do professor.

Os procedimentos didáticos devem ser aplicados visando os verdadeiros desejos e interesses do aluno. Segundo TACCA (in KELMAN, 2008b, p. 18), elas se orientam para a relação social que passa a ser uma condição para aprendizagem, pois só ela dá possibilidade de conhecer o pensar do outro e interferir nele.

Outros procedimentos didáticos é elaborar relação de significação entre conhecimento prévio que o aluno traz e o conhecimento que será adquirido na escola. (TACCA, in KELMAN, 2008B, p. 18) Ensinar significa mais do que transmitir conteúdo: implica atuar, procurando atingir a estrutura motivacional do aluno que se encontra unida aos processos do pensamento.

\section{5 - ADEQUAÇÕES CURRICULARES NECESSÁRIAS}

As adequações curriculares visam considerar as peculiaridades de cada aluno, a partir daí elaborar estratégias educacionais que possibilite aprendizagem dos alunos com métodos apropriados às necessidades educacionais especiais. As adequações necessárias buscam a organização de um currículo dinâmico, alterável, que atenda a todos os educandos.

O projeto pedagógico da escola, como ponto de referência para definir a prática
escolar, deve orientar a operacionalização do currículo, como um recurso para
promover o desenvolvimento e a aprendizagem dos alunos, considerando os
seguintes aspectos; As adequações curriculares constituem, pois, possibilidades
educacionais de atuar frente às dificuldades de aprendizagem dos alunos. Pressupõe
que se realize a adequação do currículo regular, quando necessário, para torná-lo
apropriado às peculiaridades dos alunos com necessidades especiais. Não um novo
currículo, mas um currículo dinâmico, alterável, passível para que atenda todos os
educandos (MAJÓN, op. Cit., p. 89).

Adequações avaliativas:

Diz respeito à utilização de técnicas e instrumentos selecionados para avaliar o aluno. Busca modificações essenciais na forma de apresentação das técnicas e dos instrumentos de avaliação, a sua linguagem, de forma diversificada aos demais alunos para que possa atender as peculiaridades do ANEE. Alterações nos objetivos e conteúdos que podem ter sidos acrescidos ou eliminados, evitando conteúdos e habilidades que possam estar além da capacidade de aprendizagem do aluno. 
Caracteriza-se em adequações individuais dentro das atividades regulares, incluindo os objetivos, os conteúdos e os critérios de avaliação que correspondem às necessidades de cada aluno.

\section{6 - PROCEDIMENTOS DA AVALIAÇÃO DA APRENDIZAGEM USADOS EM SALA DE AULA}

É compreendido hoje em dia que a aprendizagem vai além da aquisição de informações a serem utilizadas em sala de aula. Podemos afirmar que os processos avaliativos que são comuns em nossas práticas afirmam a valorização da memorização e os níveis mais superiores de raciocínio.

Uma avaliação que é utilizada como instrumento do processo de ensino, aumenta a qualidade no processo ensino-aprendizagem, tendo como recursos a observação, pesquisas, debates em sala que visam mais informações, procedimentos mais informais que descrevam situações de ensino e as avaliações estejam integradas. Sendo assim a avaliação está presente em todo processo do ensino-aprendizagem, não resumindo apenas a um único momento.

Para que haja aprendizagem efetiva, favorecendo as necessidades especiais dos alunos, faz-se necessárias algumas modificações nos procedimentos didáticos, como por exemplo: atividades complementares ou atividades prévias às propostas para turma, introdução de atividades alternativas e complementares de reforço como apoio de modo a promover uma prática suplementar para consolidação da aprendizagem.

Sabemos também das modificações do nível de abstração, com recursos que utilizamos para facilitar a compreensão (ex. material concreto); nível de complexidade da atividade; eliminação de parte dos conteúdos planejados para que o aluno atue de maneira autônoma e reflexiva.

\subsection{1 - Avaliação e promoção}

A avaliação é muito importante para nortear as decisões pedagógicas em todos os aspectos do processo educacional, exercendo uma grande função nas adequações curriculares.

Para os alunos com necessidades especiais o processo avaliativo deve evidenciar os aspectos do desenvolvimento biológico, intelectual, motor, emocional, social, comunicação e linguagem. 
Observar a capacidade do aluno em relação ao conteúdo curricular para definir o estilo de aprendizagem, encontrar as motivações, capacidade de atuação, curiosidades acadêmicas, estratégias próprias de aprendizagem e condições físicas mais favoráveis para o aprendizado.

O processo avaliativo no contexto educacional deve focalizar o contexto da aula e o contexto escolar; e ao se falar na promoção dos alunos com necessidades especiais, o processo avaliativo deve levar em consideração suas adequações curriculares quando necessárias.

Para orientar a promoção ou retenção do aluno na série, alguns aspectos precisam ser considerados; como a possibilidade de o aluno ter o acesso a situações escolares regulares; sua permanência com outros alunos que favoreçam o seu desenvolvimento, comunicação, autonomia e aprendizagem.

A decisão sobre a promoção deve envolver o mesmo grupo responsável pela elaboração da adequação curricular.

A inclusão é um desafio que, ao ser devidamente enfrentado pela escola comum,
provoca a melhoria da qualidade da educação básica, pois para que os alunos com e
sem deficiência possam exercer o direito à educação em sua plenitude, é
indispensável que esta escola aprimore suas práticas, a fim de atender as diferenças.
Esse aprimoramento é necessário, sob pena de os alunos passarem pela experiência
educacional sem tirar dela o proveito desejável, tendo comprometimento um tempo
que é valioso e irreversível em suas vidas: o momento do desenvolvimento. (MOANTOAN, 2008)

Ao elaborar um planejamento de aula, devemos propor atividades abertas e diversificadas, para serem assimiladas por todos os alunos em seus diferentes níveis de compreensão, de conhecimento e desempenho, em que não sejam evidenciadas habilidades de que sabe mais ou menos. As atividades são aplicadas de acordo com as possibilidades de desenvolvimento de cada aluno, após serem livremente escolhidas e refletidas por eles.

\section{7 - AlguMAS PRÁticas COTIDIANAS DE ATUAÇÃo DE EQUIPES MULTIDISCIPLINARES E INTERDISCIPLINARES NA AVALIAÇÃO E ACOMPANHAMENTO DOS ANEES}

Uma verdadeira escola inclusiva nos faz refletir sobre questões que não estávamos acostumados nem preparados para investigá-las. E sem dúvida, hoje a avaliação dessa 
inclusão está sendo a mais observada, e é a avaliação do desempenho dos alunos que demonstrará a eficácia ou não escolar.

De acordo com Vigotski (In KELMAN, 2008, p. 21),

\begin{abstract}
"O indivíduo deficiente tem um desenvolvimento qualitativamente diferente do indivíduo normal. Não é uma questão quantitativa, onde se retira a função debilitada do desenvolvimento normal para compreender a criança deficiente. Para esse, qualquer deficiência origina estímulos para a formação de compensações que irão diferenciar qualitativamente o desenvolvimento dessa pessoa".
\end{abstract}

As avaliações visam fundamentar as práticas cotidianas de ensino e fundamentar as estratégias das equipes especializadas para a inclusão e acompanhamento do processo educacional dos alunos com necessidades educacionais especiais no ensino fundamental.

Segundo Silvio Luiz (2002), a abordagem qualitativa possui a facilidade de poder descrever a complexidade de uma determinada hipótese ou problema, nos permite analisar a interação de certezas variáveis, possibilitando compreender e classificar processos dinâmicos experimentados por grupos sociais, bem como, apresentar contribuições no processo de mudança, criação ou formação de opiniões de determinado grupo, permitindo em maior grau de profundidade, a interpretação dos comportamentos ou atitudes dos indivíduos.

Ao pesquisar sobre avaliação descobrimos várias técnicas e muitos métodos anunciados para resolver os problemas relacionados a ela.

O profissional de educação realizará com presteza uma avaliação reconhecendo a legitimidade de cada aluno para participar no diálogo, situando em uma dinâmica de aprendizagem cooperativa.

Utilizar o tempo de aula para dedicá-lo a tarefas para aprender, descobrir, refletir, recrear, dialogar, compreender, enriquecer-se com os bens culturais transformando o tempo de aula em tempo de aprendizagem facilitando, estimulando, ajudando, orientando pelo ensino, deve converter-se em uma oportunidade simultânea de avaliação. (SANT'ANNA, in MARTINS, 1995, p. 50) 


\section{II - OBJETIVOS}

\section{1 - OBJETIVO GERAL}

*Identificar as concepções sobre as formas de avaliação utilizadas por uma escola pública da cidade de Planaltina D.F. e refletir se a instituição está contribuindo para o processo de inclusão escolar dos alunos com necessidades especiais das séries iniciais desta escola.

\section{2 - OBJETIVOS ESPECÍFICOS}

*Verificar as estratégias de avaliação utilizadas com o ANEE na escola pesquisada.

*Elaborar estratégias para transformação de resultados insatisfatórios que preocupam todos os envolvidos na construção do conhecimento.

*Propor alternativas para que possam auxiliar na avaliação do ANEE.

* Relatar as principais dificuldades encontradas pelos professores no momento da avaliação do ANEE.

*Estimular a capacitação dos professores e melhoria dos resultados alcançados. 


\section{III - METODOLOGIA}

Utilizando abordagem qualitativa, possibilitou-me detectar os elementos essenciais à análise dos fenômenos que ocorre no conjunto das relações entre diferentes sujeitos da ação.

Este trabalho utilizou a abordagem qualitativa porque se constituiu a mais favorável, pois a partir dela foi possível buscar compreender a avaliação da aprendizagem em várias dimensões. Para isso utilizei pesquisa de campo e estudo teórico.

De acordo com DEMO (1989; p. 12), essa metodologia trabalha sempre com unidades sociais, pois privilegia os estudos de caso - entendendo-se como caso: o indivíduo, a comunidade, o grupo, a instituição.

Para organização da pesquisa iniciei com os (as) professores (as) que estão diretamente trabalhando com esta clientela (ANEE) na escola. Foram realizadas entrevistas quanto às expectativas de desenvolvimento dos mesmos e com os pais e os alunos destes professores. Analisei se as estratégias propostas no Projeto Político Pedagógico (PPP) estão sendo postas em prática, assim como o desenvolvimento das aulas e adequação do currículo à cada necessidade do aluno.

Por eu ser professora de sala de recursos, tenho acesso aos dados da secretaria em relação ao ANEE, conversas diárias com as professoras regentes e demais funcionários que prestaram e prestam apoio aos alunos quando solicitados e participo da elaboração do PPP da escola.

\section{1 - Contexto da pesquisa}

a) A escola:

A Unidade de Ensino atende cerca de 640 crianças, onde 16 alunos apresentam necessidades educacionais especiais. Trata-se de uma escola de ensino fundamental. Dos 20 professores regentes, 14 estão em média com um ANEE.

b) Direção e coordenação pedagógica:

A coordenação pedagógica ocorre de forma interativa: a coordenadora dos turnos: matutino e vespertino atua como intermediária juntamente com a Supervisora Pedagógica entre professores e direção, procurando intermediar e estimular o trabalho coletivo e a ação pedagógica. 
Os professores coordenam todos os dias em turno contrário da regência e fazem coordenação coletiva todas as quartas-feiras para elaboração dos projetos interventivos e avaliação do percurso.

c) Sala de Orientação Educacional e Sala de recursos:

Na SOE tem a pedagoga que faz intercâmbio entre os professores e pais, com o objetivo de diagnosticar e resolver dificuldades de aprendizagem faz encaminhamentos dos alunos com possíveis problemas, colabora com a coordenação dos projetos da escola, desenvolve atendimentos aos alunos com dificuldades de aprendizagem para buscar e analisar juntamente com o professor regente se há motivos para encaminhamento à psicóloga que é itinerante.

A sala de recursos esta sempre em busca de equipamentos que melhore e contribua com recursos necessários para atender os alunos com necessidades educacionais especiais em suas peculiaridades; existe intercâmbio entre professores regente e da sala de recursos, para acompanhar o desempenho dos alunos no decorrer do processo. $\mathrm{O}$ atendimento nesta sala é específico aos alunos diagnosticados, para sanar as dificuldades apresentadas quanto a conteúdos bem como habilidades funcionais e relacionamento social.

\section{2 - Participantes}

Diante ao tema da pesquisa, realizei um questionário com 09 professores que trabalham com ANEE com idade média de 30 a 35 anos, 10 anos na profissão, sendo 1 com experiência de inclusão a 5 anos e os demais a 2 anos; 03 pessoas da equipe diretiva (diretora, vice-diretora e supervisora pedagógica) e 03 pais dos alunos diagnosticados, 2 Deficientes Intelectuais e 1 com Transtorno Déficit de Atenção/ hiperatividade e Dislexia cursando $3^{\circ}$ ano e $2^{\circ}$ ano respectivamente.

\section{3 - Materiais utilizados na pesquisa}

Para realização deste trabalho fez-se necessário a utilização da metodologia qualitativa, utilizando entrevistas, questionários e análise do PPP. 
Além dos livros, foram utilizados como apoio bibliográfico os módulos do curso e livros das Orientações Pedagógicas da sala de recursos fornecidos pela SEDF, bem como materiais informativos oferecidos pela mesma.

Para coleta de dados com os instrumentos citados acima utilizamos os seguintes materiais:

$$
\begin{aligned}
& \text { *Papel } \\
& \text { *caneta }
\end{aligned}
$$

\section{4 - Instrumentos de construção de dados}

Foram utilizados para realização desta pesquisa questionários respondidos pelos professores e equipe diretiva, para os pais foram feitas entrevistas oralmente respondidas. Que estão em anexo ao final do trabalho.

\section{5 - Procedimentos de construção de dados}

A pesquisa aconteceu em uma escola de Planaltina DF, por eu estar trabalhando em sala de recursos há 03 anos e sentir o quanto é difícil para os professores avaliar ANEE. Cada um dos seguimentos: 03 pais, 09 professores e 03 profissionais da equipe gestora da escola, foram escolhidos por estarmos buscando juntos uma avaliação para melhor desenvolvimento de estratégias para efetivo aprendizado destes alunos e com base no desenvolvimento de seus papéis na inclusão dos alunos. Para coleta dos dados o estudo foi composto pela aplicação de questionários aos professores e equipe diretiva, uma entrevista aos pais e análise da proposta pedagógica da escola.

Sendo assim, para análise satisfatória, foram entregues e respondidos pelos professores nove questionários, pela equipe diretiva três questionários e três pais participaram da entrevista.

Procurando não comprometer a rotina da escola, pela dificuldade do encontro com os professores e direção que se encontrava na mesma, cada participante respondeu individualmente seus questionários e no momento da entrega conversamos para rever possíveis questionamentos e/ou sugestões. 
Buscando mais segurança por parte dos pais, pois os mesmos são analfabetos funcionais, preferi anotar as respostas ao ponto que iam falando.

A aplicação dos questionários com os professores gerou um debate, onde fez com que vários deles defendessem suas respostas e consequentemente passaram a interrogar sobre suas incertezas, dúvidas e curiosidades. Deixando claro que a escola deveria incluir um projeto voltado para o tema em função do surgimento de interrogações.

Pude observar que o Projeto Político Pedagógico da nossa escola não incluía a avaliação do desempenho dos nossos alunos e que sem um planejamento de metas a serem conquistados deixava os professores com uma "liberdade" que podia fazer com que os nossos alunos sentissem desestimulados.

Já com os pais, eles mal sabiam registrar as suas expectativas em relação ao desenvolvimento do seu filho, mas possuíam sonhos, desejo de realização e muita vontade de participar do progresso de seu filho.

A direção da escola no início sentiu-se cobrada, tentando justificar a falta de incluir metas, planejar atitudes para esses alunos, mas em seguida promoveram na escola algumas palestras sobre os direitos, a obrigação da escola e sociedade como um todo.

A escola juntamente com os pais e funcionários, se comprometeram a modificar as atividades que serão desenvolvidas ainda este ano e garantiu que além de promover mais estudos sobre o tema, também não deixará esses alunos sem acompanhamento, sem estímulos e tão pouco acontecendo uma inclusão que não sai da parte burocrática. 


\section{IV - RESULTADOS E DISCUSSÃO:}

Passamos a refletir que avaliação não é um fim em si mesmo, primeiramente deve nortear decisões pedagógicas para rever a prática. Desta forma buscamos pressupostos de uma avaliação formativa onde o aluno e o professor acompanham o desenvolvimento da aprendizagem, rompendo com a concepção homogeneizadora do ensino.

\section{QUESTIONÁRIO E RESPOSTAS DOS PROFESSORES}

$\mathrm{N}^{\mathrm{o}}$ de participantes nesta pesquisa: 09

1- Que tipo de avaliação utiliza comumente?

( )formativa

( )classificatória

( X diagnóstica e formativa ( Todos responderam)

( )

2- A avaliação do aproveitamento educacional do ANEE deve utilizar instrumentos e estratégias diferenciadas? Por quê?

P1: Sim, para elaborar atividades de acordo com seu desempenho.

P2: Sim.

P3: Sim, com o objetivo de observá-lo em diferentes estratégias e recursos.

P4: Sim, conforme cada deficiência.

P5: Sim.

P6: Sim, a fim de não buscarmos a padronização dos conhecimentos.

P7: Cada aluno possui características diferentes.

P8: Sim, para melhor aprendizagem do aluno.

P9: Sim, para poder verificar o aproveitamento do aluno dentro do que ele cresceu/ conseguiu e não dentro de suas limitações. 
3- $\overline{\text { Você utiliza os mesmos critérios na correção de atividades do ANEE e dos demais }}$ alunos?

( ) $\operatorname{sim}$

( X )não

Justifique sua resposta

P1: Cada aluno possui um potencial/ habilidades específicas.

P2: Observo a deficiência e a necessidade do que é relevante para cada aluno.

P3: Utilizo a observação de cada aluno para escolher a melhor estratégia.

P4: Vai de acordo com o potencial de cada aluno.

P5: O ANEE possui capacidades diferenciadas, precisam de um auxílio mais amplo.

P6: O propósito de avaliação do ANEE é diferenciado dos outros alunos.

Os demais participantes não justificaram sua resposta.

4- $\mathrm{O}$ atendimento em sala de recursos e/ou apoio, em sua opinião, melhora o desempenho do ANEE em sala de aula? Como?

P1: Sim, pelo atendimento individualizado.

P2: Sim, por poder atendê-los individualmente.

P3: Sim, pela facilidade de trabalho com material concreto e apoio constante.

P4: Sim.

P5: Sim, mas desde que seja com um tempo maior e mais vezes por semana.

P6: Sim, como o atendimento é mais individual, o aluno ganha maior atenção e segurança para utilizar os propósitos feitos.

P7: Sim, tornando-os mais independentes.

P8: Sim.

P9: Sim, com apoio didático específicos às necessidades dos alunos. 
5- Quais os métodos de avaliação utilizados para o ANEE?

P1: Avaliação de acordo com seu desenvolvimento, caso precise repetir os conteúdos damos prioridade para que revejam.

P2: Avaliação processual e formativa.

P3: Depende da necessidade do aluno.

P4: Comportamento, desempenho nas tarefas.

P5: Observação das atividades realizadas diariamente.

P6: Avaliação formativa.

P7: De acordo com a deficiência e habilidade do aluno.

P8: Observação e destreza nas atividades.

P9: Através de jogos e brincadeiras.

6- Qual a porcentagem de ANEE aprovados no ano de 2009 e 2010?

*Ninguém soube responder.

7- Você elabora Adequação curricular para seus ANEE? Quanto tempo você precisa para escolher e/ou desenvolver a melhor estratégia para seu aluno?

P1: Sim, conforme as informações da Secretaria de Educação.

P2: Sim, Com base nos relatórios do aluno, conhecendo o aluno, sua necessidade, baseando-se no currículo e com apoio da professora da sala de recursos.

P3: Sim, mais ou menos uma semana.

P4: Sim, depois de observar os alunos.

P5: Sim, após mais ou menos um mês de observação.

P6: Sim, após observação do aluno, conhecimento do relatório do ano anterior.

P7: Sim, após conhecimento dos relatórios e observação do aluno e apoio da sala de recursos.

P8: Sim, após conhecimento do aluno. 
P9: Sim, Após conhecimento da deficiência, observação do aluno em sala, relatórios anteriores.

8- Quantos ANEE são atendidos nessa escola?

Não sabiam.

9- Quando você recebe um ANEE procura se informar sobre as melhores estratégias de ensino para este aluno e sobre sua deficiência? Por quê?

P1: Sim, para facilitar meu trabalho e saber como eu agir com ele.

P2: Sim, porque o professor deve servir de facilitador da aprendizagem.

P3: Sim, para atender melhor o aluno.

P4: Sim, porque ajuda no desenvolver das estratégias.

P5: Sim, Para escolha das estratégias.

P6: Sim, para planejar as estratégias.

P7: Sim, para melhor definir as estratégias e adequar os conteúdos.

P8: Sim, porque facilita na escolha dos procedimentos.

P9: Sim, conhecendo sobre a deficiência do aluno, posso adequar o currículo às suas necessidades.

10- Em sua opinião o que faltou e falta para um melhor desempenho nas estratégias de ensino aprendizagem para o ANEE que você atende?

P1: O que de fato é necessário para que haja uma inclusão são recursos, empenho e atendimento necessário ao aluno ANEE. Pois a inclusão não é só colocar o aluno em contato com os outros colegas, mas dar um suporte para que o aluno possa aprender conforme seu desenvolvimento.

P2: Mais rapidez nos diagnósticos.

P3: Fazer as adequações curriculares em tempo menor.

P4: Maior envolvimento da família com a escola e aluno.

P5: Falta de maior capacitação de minha parte, turma muito agitada não permitindo oferecer a atenção e o tempo que meu aluno com necessidades educacionais necessita. P6: Falta de maior auxílio por parte da U.E., falhas no sistema da Secretaria de Educação. 
P7: Mais capacitação.

P8: Falta de recursos didáticos e físicos da Instituição.

P9: Uma estratégia de matrícula que colabore com um número reduzido de alunos por turma, melhores condições didáticas, oferecimento de cursos de capacitação a todos os profissionais de educação.

\section{Com relação às respostas dos professores}

Dos nove (09) professores que tem alunos com ANEE (09) responderam ao questionário, confirmando a grande importância que é dada ao tema pelos educadores, tendo em mente sua complexidade.

\footnotetext{
"Os questionários podem conter perguntas abertas e fechadas e as respostas podem ser obtidas de maneira livre, ou perguntas fechadas limitadas a determinadas respostas tipo respostas com $\mathrm{X}$ ou com números (FARIA, CUNHA, e FELIPE, 2008, P.40)"
}

Cinco (05) professores acreditam avaliar os seus alunos de maneira diagnóstica e formativa e o mesmo quantitativo afirma que utiliza vários instrumentos para detectar a avaliação foram: através da participação oral nas aulas, observação, da conclusão, das atividades propostas, leitura, realização das atividades em sala de aula, trabalhos, observação de conhecimentos prévios de forma formal e informal, observação do contexto familiar, autoavaliação, assiduidade, trabalhos em grupo, atividades desenvolvidas em casa, comportamento anotação e registro das atividades diárias relacionamento interpessoal cadernos, testes escritos e orais que vão de acordo com a deficiência. No entanto observei que embora alguns professores utilizem esses instrumentos variados, em muitos casos, esses não são considerados, pois esses professores dão maior importância à avaliação formal no modelo: provas e trabalhos escritos.

\footnotetext{
“A combinação da avaliação baseada em critérios com a consideração das condições do aluno fornece informações importantes e é consistente com a ideia de que a avaliação formativa é parte essencial do trabalho pedagógico." VILLAS BOAS, (2004, p. 32)
} 
Dois (2) professores não utilizam desses resultados para replanejar suas aulas. Notei então, que 01 dos 09 professores que acredita utilizar a avaliação formativa, até utiliza vários instrumentos, porém não se utiliza desses resultados para replanejar seu trabalho pedagógico.

\footnotetext{
"Argumenta que toda avaliação deve ter um caráter dinâmico, voltado para uma análise prospectiva das possibilidades de aprendizagem e desenvolvimento da criança, ao invés de se caracterizar como uma mera retrospectiva da aprendizagem alcançada (ou não alcançada) por ela.” VIGOTSKI (2001 p.195)
}

Houve unanimidade por parte dos professores ao afirmar que a principal função da avaliação é propiciar intervenções pedagógicas, pois, por meio desses resultados eles podem observar o que os alunos têm mais dificuldade e a partir daí revisar aquele conteúdo.

A conceituação de avaliação diagnóstica ou formativa por parte dos professores chamou a minha atenção porque revela o alto grau de conhecimento que os professores dispõem a cerca do tema avaliação em seus discursos. No entanto a concepção é da avaliação tradicional. $\mathrm{Na}$ avaliação formativa analisamos o trabalho do estudante, a organização do trabalho pedagógico e da escola.

A falta de recursos foi um dos aspectos mais apontados como dificultador a execução das práticas diferenciadas para atender o ANEE, acompanhado do pouco envolvimento da família, mais preparo por parte dos professores e falhas no sistema da S.E.D.F.

Quanto ao atendimento em sala de recursos, todos concordam que melhora o desempenho do ANEE, mas que ele deveria acontecer com mais freqüência semanal, pois o atendimento é mais individual e o aluno ganha maior atenção e segurança para utilizar os propósitos feitos.

Com relação à observação das avaliações aplicadas pelos professores verifiquei ainda certo apego a semanas de provas, com datas estipuladas para cada disciplina principalmente $3^{\text {a }}$ e $4^{\mathrm{a}}$ séries, o que dificulta tanto por parte dos professores como por arte dos pais ao receber um relatório, sem uma prova respondida e sim a utilização de diferentes métodos para avaliação. Apesar de os professores estarem buscando um novo conceito em avaliação, que podemos chamar de avaliação diagnóstica e formativa, encontrei muitos resquícios da avaliação tradicional, baseada em um único instrumento que determinará o conceito final do ANEE, embora muitos outros sejam aplicados. 
“... é preciso olhar. Olhar o que a criança sabe, o que ela tem, o que ela pode, o que ela gosta. Não se propõe nenhuma tarefa previamente definida, não se pergunta se sabe fazer determinada coisa, mesmo que seja empinar pipa ou jogar bolinha de gude. Pergunta-se o que ela sabe fazer. E, a partir daí, o profissional busca, nestas atividades, nas expressões que ela já adquiriu, o que subsidia e permite estas expressões. Ao invés de a criança se adequar ao que o profissional sabe perguntar, este é quem deverá se adequar às suas expressões a seus valores, a seus gostos." MOISÉS e COLLARES (1997 p. 15)

\section{PERGUNTAS E RESPOSTAS DA ENTREVISTA COM OS PAIS}

$\mathrm{N}^{\mathrm{o}}$ de participantes nesta pesquisa: 03

Deficiência de seu (a) filho (a): 1 TDAH e dislexia / 2 deficientes intelectuais

Série que ele cursa: $4^{\mathrm{a}}$ série $/ 2^{\circ}$ ano $/ 2^{\circ}$ ano

Possui adequação curricular? ( X )sim ( )não

1) Você acompanha as atividades que seu (a) filho (a) realiza na escola?

P1: Ás vezes

P2: Ás vezes

P3: Ás vezes

2) Você concorda que a avaliação de seu (a) filho (a) corresponde à necessidade educacional dele?

P1: Sim

P2: Sim

P3: Sim

3) Você acredita que as práticas de avaliação utilizadas pelos professores da escola ajudam na melhor escolha das estratégias para educação de seu (a) filho (a)? Ou 
apenas são avaliações classificatórias que não respeitam a necessidade de seu (a) filho (a)?

P1: Sim

P2: Sim

P3: Sim

4) Quando você expõe suas opiniões a respeito do desenvolvimento de seu (a) filho (a)? ( $\mathrm{X}$ ) sempre que necessário ( todas responderam)

5) Como você avalia o desenvolvimento de seu (a) filho (a)?

Aspectos positivos

*Todos acreditam que na sala os professores ajudam e que na sala de recursos eles gostam das atividades que fazem.

Aspectos negativos

P1: Muito pouco ele aprende; Falta de psicólogo na escola.

P2: Desenvolvimento lento, atividades diversificadas para desenvolver habilidades físicas.

P3: A escola não está bem preparada com atividades em período integral para todos alunos especiais.

6) Você deseja ressaltar algo para melhor aproveitamento das avaliações de seu (a) filho (a)?

*As mães entrevistadas ficam ansiosas na expectativa de verem seus filhos desenvolvendo atividades como os outros ditos normais.

OBRIGADA! 


\section{Com relação às respostas dos pais}

Através da entrevista e diante das respostas dos pais em questão pude notar que os mesmos estão verdadeiramente engajados no propósito de apoiar os filhos, uma das 03 mães me confidenciou que não se sente à vontade ainda com este diagnóstico do filho porque obteve este ano o laudo.

Das 03 mães entrevistadas, 02 tem filhos com diagnóstico de deficiência intelectual e 01 com filho com diagnóstico de TDAH e dislexia, onde todos possuem adequação curricular.

A entrevista foi realizada por meio de perguntas estruturadas. "As entrevistas são estruturadas quando são formuladas questões de maneira prévia, e não estruturadas quando em conversação objetiva são obtidos os dados relevantes (Manual Prático para elaboração de monografias, 2008, p.40)".

Durante as entrevistas pude observar o envolvimento de todos com os filhos, mas acrescento que não há este envolvimento por parte de todos os pais de ANEE nesta escola, pois muitos não se importam acreditando que se é deficiente não tem mais nada que fazer; alguns professores acreditam que é por falta de informação visto que $80 \%$ dos pais de alunos são analfabetos funcionais, vindos de um lar desestruturado e criados por algum parente.

Os pais em geral só compreendem as avaliações, como motivo de aprovação ou reprovação e observam que os filhos não fazem as "provas" como os outros alunos, estas mães entrevistadas disseram que expõe suas opiniões a respeito do filho sempre que necessário, pois mesmo sem saber direito o que fazer sabe que eles precisam se desenvolver.

\footnotetext{
"A função da avaliação da aprendizagem seria de auxiliar a construção da aprendizagem satisfatória; porém, como ela está centralizada nas provas e exames, secundária o significado do ensino e aprendizagem como atividades significativas em si mesmas e superestima os exames". LUCKESI (2008, p. 25)
}

Estas mães avaliam o desenvolvimento de seus filhos como muito lento, e que a escola não está preparada para ajudar, pois não tem atividades o suficiente e acham que estes necessitam de acompanhamento com psicólogo e a falta de estrutura física. Mas ressaltam que os professores estão fazendo o que sabem e tem condições de fazer. 
Acreditam que a adequação curricular auxilia no respeito às limitações de seus filhos, mas ainda estão inseguros quanto à aprovação dos mesmos sem estar no mesmo nível da turma que pertencem.

\section{QUESTIONÁRIO E RESPOSTAS DOS GESTORES:}

$\mathrm{N}^{\mathrm{o}}$ de participantes nesta pesquisa: 03

1) Você já participou de palestras ou cursos que abordam o tema ANEE?

P1: Sim

P2: Sim

P3: Sim

2) Já participou de palestras ou curso sobre avaliação?

P1 : Sim

P2: Sim

P3: Sim

3) As práticas avaliativas utilizadas pelos professores em sua escola, visam as características peculiares de cada ANEE?

P1: Às vezes

P2: Às vezes

P3: Às vezes 
4) Como você classifica o preparo dos professores para trabalhar com o ANEE?

P1: Bom

P2: Ruim

P3: Ruim

Por quê?

P1: Bom, pois buscam atender as particularidades dos alunos dentro do possível, porém precisam melhorar a sua prática.

P2: É comum ouvirmos os próprios professores dizer que não sabem o que fazer com o ANEE.

P3: Faltam cursos específicos para melhorar a prática destes professores em sala.

5) Como a equipe gestora desta escola compreende a avaliação escolar do aluno ANEE?

P1: A avaliação a ser trabalhada de forma que o aluno ANEE tem uma aprendizagem mais igualitária possível, mais justa.

P2: Assim como a dos outros alunos, a avaliação do ANEE deve ser formativa, respeitar o ritmo de cada um.

P3: Como um meio de inseri-los de uma forma mais justa no ensino regular.

6) A equipe gestora propõe discussões pedagógicas a respeito da avaliação escolar do ANEE com o grupo de professores da escola? E com a comunidade escolar?

P1: Sim principalmente quando desenvolvemos o projeto da Ed. Inclusiva em que toda escola e comunidade escolar participam (Funcionários, professores, alunos, etc.)

P2: A equipe gestora tem falhado nesse quesito. 
P3: Mais especificamente na semana da inclusão sob a responsabilidade da Sala de Recursos.

7) Você quer ressaltar alguma observação que possa contribuir com um melhor desenvolvimento e aproveitamento para avaliação do ANEE?

P1: Levar o grupo docente à participar mais, estudar, se integrar.

P2: A formação dos educadores poderia contribuir para um melhor desenvolvimento.

P3: Fazer mais reuniões com o grupo de professores para tratar do aluno ANEE.

\section{OBRIGADA!}

\section{Com relação às respostas dos gestores}

A diretora, vice-diretora e supervisora pedagógica da escola já participaram de curso ou palestra sobre a avaliação do ANEE e acreditam que a escola está em processo de mudança, ou seja, de transição, visto que, ainda guardam resquícios da avaliação tradicional.

Concordo com a equipe gestora que práticas efetivas de avaliação do ANEE estão em fase de transição porque não percebemos no dia-a-dia os professores utilizando-se desses diversos instrumentos como elemento facilitador da prática pedagógica, porém não os utilizam adequadamente.

“... faz uma crítica ao modelo mecanicista de aprendizagem e desenvolvimento, no qual a representação do aluno não passa de uma máquina, um robô a ser treinado, condicionado pela figura autoritária do professor, sem que se leve em conta o "sujeito social constituído intrinsecamente por relações sociais, culturais e históricas". WERNER (2000, p.77), 
Para elas, a função da avaliação é diagnosticar para intervir e verificar o nível de aprendizagem dos alunos. Avaliação do ANEE tem por base a individualidade, aquela que atende o físico (motor) social e cognitivo do aluno, sua deficiência. Compreendem a avaliação como instrumento diagnosticador e como forma de buscar melhorias para a qualidade do ensino.

\footnotetext{
"A avaliação escola está voltada para a promoção da aprendizagem do aluno. A aprendizagem e avaliação andam de mãos dadas a avaliação sempre ajudando a aprendizagem". VILLAS BOAS (2004, p.29),
}

A diretora e vice-diretora acreditam que propõe discussões a respeito da avaliação escolar com os professores e com a comunidade escolar no momento em que se desenvolve o Projeto Inclusão, mas a supervisora pedagógica acredita que ainda a falhas quanto a estas discussões. No entanto a equipe gestora articula com os professores da escola, demonstrando assim certa preocupação com práticas avaliativas mais processuais e que atendam a aprendizagem do aluno e o aperfeiçoamento do professor.

A equipe gestora acredita que necessita de mais conhecimento sobre o tema e irá contribuir muito para esse trabalho de articulação que leve à reflexão a cerca do tema. Essas mudanças de atitude resultaram em alterações no projeto político pedagógico por meio de ações específicas objetivando o desenvolvimento de habilidades e competências contempladas pelo uso de práticas de avaliações de acordo com a necessidade de cada ANEE.

\section{Relatório da Proposta Pedagógica}

Analisando a proposta pedagógica da desta Unidade de Ensino, observei que quando se refere à avaliação, ela está num contexto geral para todos os alunos, não especificando avaliações alternativas aos alunos com necessidades educacionais especiais.

Esta proposta pedagógica traz pressupostos de uma avaliação formativa e processual, instigando ao professor a desenvolver no aluno atos de buscar aprender por meios de atitudes que incentivem o aluno a propor soluções para os problemas levantados. 
Segundo a proposta, a avaliação terá um papel investigador, analisando coletivamente os objetivos alcançados e sendo capaz de apontar possíveis erros encontrados para elaborar novas estratégias de ensino-aprendizagem.

"A avaliação não deveria ser fonte de decisão sobre o castigo, mas de decisão sobre os caminhos do crescimento sadio e feliz". LUCKESI (2008, p.58),

Um tema relevante da proposta pedagógica: superando a exclusão; garante a permanência de todos os alunos numa escola prazerosa propiciando condições para o sucesso escolar.

Observo que a avaliação está pautada nas concepções de FREITAS: "A avaliação incorpora os objetivos, apontando uma direção (1995, p. 95)". Que sugere que esta seja utilizada para possível retomada de atitudes, não apenas como levantamento do sucesso ou fracasso do aluno.

Acredito que o hábito de avaliar deve acontecer diariamente, respeitando os limites, sentimentos, dúvidas e dificuldades pessoais.

Percebo que valorizar o histórico familiar do aluno, bem como estímulo que o mesmo receba, incentivar a curiosidade e intervir para a construção do conhecimento são atitudes que dividem com todos da escola o sucesso no desenvolvimento e na aprendizagem.

Avaliar deve ter como objetivo principal o desenvolvimento do aluno que busque rever ações e planejamentos diversificados que consigam abranger todos os que fazem parte da escola.

A escola deve apontar as atribuições e as obrigações que todos os profissionais devem possuir para garantir o desenvolvimento dos alunos. Após a pesquisa, percebemos que ainda necessitamos desenvolver habilidades para respeitar as diferenças, para melhor desempenho dos alunos e buscar maneiras de avaliar com o objetivo de valorizar, investigar e diagnosticar as possíveis dificuldades para intervir na melhor maneira do desenvolvimento intelectual e social dos mesmos. 


\section{V - CONSIDERAÇÕES FINAIS}

O desenvolvimento dos alunos com necessidades educacionais especiais no Ensino Fundamental levou-me ao interesse de observar e analisar os procedimentos de avaliação, para apontar alternativas nesse processo, que não devem ser conclusivas, visto que o processo só se tornará válido se levar em conta o contexto a que o aluno pertence.

A inclusão ainda está em processo de estudo, os profissionais em educação estão aprendendo na prática e na busca de informações teóricas para que possam contribuir com o desenvolvimento dos alunos. Mas as contribuições dos participantes na pesquisa constituíramse em elementos válidos que vão ao encontro com os objetivos desta monografia.

Os profissionais desta instituição buscam atingir o interesse dos alunos pela escola. Mas ainda estão em processo de transição entre uma avaliação tradicional e uma avaliação formativa e qualitativa, há evidências de práticas diversificadas de avaliação, prevalecendo provas, deixando por último a avaliação informal com objetivo de alterar os procedimentos didáticos a fim de identificar estratégias que vão de encontro ao que os alunos se interessam.

Há um consenso entre os professores e equipe gestora por uma avaliação com objetivo de orientação do planejamento pedagógico e da efetiva aprendizagem do aluno especial ou não; porém necessita de uma reflexão, principalmente por parte dos pais que ainda estão presos a importância das notas das provas como resposta ao aprendizado ou não de seus filhos.

Com base na pesquisa e observação/acompanhamento do trabalho pedagógico dos professores, posso afirmar que o processo avaliativo do ANEE desta escola, respeita a adequação curricular de cada aluno, levando em consideração os aspectos físico, intelectual, emocional e social para aquisição das habilidades propostas.

A Escola pesquisada propõe através da filosofia desenvolvida na Sala de Recursos, o desenvolvimento de uma aprendizagem a partir de situações contextualizadas, da visão do aluno, respeitando suas necessidades educacionais especiais e suas limitações.

No desenvolvimento desse trabalho, ficou claro que na escola pesquisada o processo avaliativo considera que, seja qual for a alternativa utilizada para avaliar a aprendizagem do aluno, que ela esteja a serviço de quem aprende. Que a avaliação é para que os professores e 
alunos detectem as competências e os conhecimentos adquiridos, assim como se as estratégias são adequadas e significativas para o processo de aprendizagem do aluno.

Pode-se perceber que a inclusão precisa sofrer algumas adequações no que diz respeito a avaliação do ANEE, pois, para que atinja seus objetivos é preciso respeito as particularidades e peculiaridades de cada um, condições favoráveis de aprendizagem, para compensar suas dificuldades.

Posso concluir que precisamos correr para construirmos uma escola inclusiva, apesar das barreiras e dos obstáculos a serem transpostos, estamos dando o primeiro passo, mas para atingir o sucesso é necessário aprendermos com as práticas educativas existentes, às vezes para inovar precisamos compreender o velho e ao realizar o novo, transformá-la em moderna.

Ao desenvolver seu processo de ensino, nós professores devemos manter alguns cuidados necessários com a avaliação da aprendizagem escolar. A avaliação deverá compreender a função do educando e a do educador, deixar claro que os resultados alcançados pelos alunos também avaliam a maneira que o professor passou o conteúdo para o aluno. $\mathrm{O}$ professor deverá buscar resultados satisfatórios de aprendizagem e caso isso não ocorra modificar seus planejamentos para encontrar maneira de conquistar o sucesso na aprendizagem.

A escola pesquisada mostrou-se bem comprometida em relação a avaliação na inclusão e os professores que atendem o ANEE se reúnem com a equipe de apoio especializado para elaborar avaliações diferenciadas. Com certeza esse trabalho oportunizou uma reflexão sobre o método de avaliação, que reafirma o compromisso com o ANEE. Pois, por mais que sabemos, aprendemos a cada reflexão, é preciso perceber a complexidade e a responsabilidade em desenvolver uma aprendizagem significativa para os alunos especiais.

Em suma, com os resultados de uma avaliação podemos reelaborar um planejamento e flexibilizar atividades às necessidades do aluno especial, assim desenvolver um processo de ensino-aprendizagem coerente e significativo ao mesmo.

Entendo que o professor regente após o conhecimento/observação e estudo do caso de seu aluno especial é quem dará as instruções iniciais para a busca das estratégias necessárias à plena participação do aluno no processo de ensino e aprendizagem, considerando suas necessidades específicas. 
Em sala de aula, se estreitam os laços entre professor-aluno, sendo capaz de o professor identificar metodologias para contribuir no desenvolvimento de habilidades e competências curriculares e sociais.

Nessa perspectiva, é de suma importância o professor considerar se em sua adequação houve articulação de recursos e estratégias que promovem o interesse e as capacidades que aprimoram o funcionamento pessoal do aluno, para poder avaliar de acordo com as características da necessidade especial.

As ações dos professores frente aos resultados de uma avaliação preferencialmente formativa devem, portanto, ser fundamentadas na melhoria de suas condições de aprendizagem. O papel principal do professor é quanto à definição do nível de competência curricular do aluno, bem como a identificação dos fatores que interferem no processo de ensino e de aprendizagem.

Os procedimentos didáticos dos professores devem ser norteados e fundamentados em critérios que identificam o que o aluno deve aprender, como e quando ele deve aprender, que metodologias de ensino são mais eficientes para o processo de aprendizagem como e quando avaliar.

Para auxiliar na avaliação do ANEE, o professor não pode considerar o currículo ou adequação curricular, inflexível e estático para o aluno, mas sim que a dinâmica criativa do professor é importante ao desenvolvimento do mesmo.

Sugiro, para tanto, utilização dos instrumentos de avaliação funcional (O currículo funcional envolve atividades relacionadas ao desenvolvimento de habilidades adaptativas, tais como: consciência de si, cuidados pessoais e vida diária, treinamento multissensorial, exercício da independência, relacionamento interpessoal, dentre outras habilidades.) para conhecimento dos interesses e necessidades das potencialidades a serem desenvolvidas; elaboração do planejamento individual; registro contínuo e avaliação processual a fim de uma reavaliação pedagógica do aluno.

Exemplo de estratégias

Adequar os objetivos, ou até mesmo priorizar objetivos conteúdos e critérios de avaliação, considerando as condições do aluno em relação aos demais colegas da turma. 
Mudar a temporalidade dos objetivos, conteúdos critérios de avaliação, considerar que o ANEE possa alcançar os objetivos comuns à turma mesmo que exija um tempo maior. Necessitando de um período variável para o processo de ensino-aprendizagem.

Aplicar conteúdos, objetivos e critérios de avaliação, considerando possibilidades de acréscimo na ação educativa caso necessário ao ANEE.

Eliminar conteúdos, objetivos e critérios de avaliação, não devendo causar prejuízo para sua escolarização e promoção; considerar se a supressão desses objetivos e conteúdos são básicos e fundamentais para aprendizagens posteriores.

Sabe-se que não é apenas a qualificação profissional do professor inicial e continuada, fator indicativo de sua competência para atuar com ANEE. È indispensável que tenha qualidades humanas e desempenho profissional para tal função. Isso porque muitas de suas dificuldades escolares não estão ligadas apenas a condições pessoais, mas também a situações limitantes no ambiente físico escolar.

Para eficácia nos procedimentos avaliativos e desempenho profissional, vejo importantes fatores que o professor deve considerar:

*Pronto atendimento às suas necessidades biopsicossocial;

*Expectativas favoráveis ao seu desenvolvimento;

*Motivação para o trabalho e pesquisa;

*Abertura e flexibilidade quanto à diversidade e deficiência;

*Atitude de enfrentamento dos obstáculos à acessibilidade;

*Disponibilidade;

*Procura para capacitação profissional, iniciativa e criatividade.

Enfim, para que haja inclusão, faz-se necessário planejar um currículo acessível a todos os alunos, de modo a promover uma efetiva aprendizagem; garantindo não só o acesso como a permanência do estudante com necessidades educacionais especiais. 


\section{REFERÊNCIAS BIBLIOGRÁFICAS}

BOSSA, Nádia A. A psicopedagogia no Brasil, contribuições a partir da prática. Porto Alegre: Artes médicas, 2000.

ESTEBAN, Maria Teresa, Garcia, Regina Leite, Barriga, Angel Dias, AFONSO, Almerindo Janela. Avaliação: uma prática em busca de novos sentidos. Rio de Janeiro: DP\&A, 1999.

FARIA Ana C., CUNHA Ivan, FELIPE. Yone X. Manual Prático para Elaboração de Monografia. (Trabalhos de conclusão de curso, Dissertação e tese) São Paulo: USTJ, 2002.

GONSALVES, E.P. Iniciação à pesquisa social. 2a ed. Campinas: alínea, 2007.

HOFFANN, Jussara Pontos \& Contrapontos: do pensar ao agir em avaliação. Porto Alegre: Mediação, 1998.

HOFFANN, Jussara. Avaliação: Mitos e Desafio: Uma perspectiva construtiva. Porto Alegre: Mediação, 2003.

LUCKESI, Cipriano C, Avaliação da aprendizagem escolar. 19ª ed. São Paulo: 2008.

MORALES, Pedro. Avaliação escolar. O que é, como se faz. São Paulo:1995.

VILLAS BOAS, Benigna M. de Freitas. Portfólio, Avaliação e Trabalhos Pedagógicos. Campinas, SP. : Papirus 2004. 


\title{
APÊNDICES
}

\section{A - QUESTIONÁRIO GESTORES}

\author{
UNIVERSIDADE DE BRASÍLIA \\ UNIVERSIDADE ABERTA DO BRASIL \\ ESPECIALIZAÇÃO EM DESENVOLVIMENTO HUMANO, EDUCAÇÃO E INCLUSÃO \\ ESCOLAR
}

Venho solicitar à Equipe gestora da Escola Classe 07 de Planaltina que responda o seguinte questionário que se destina a realização de um trabalho de pesquisa, cujo tema: AVALIAÇÃO DO ANEE NAS SÉRIES INICIAIS.

Cargo ou função na U.E.:

$\mathrm{N}^{\mathrm{o}}$ de aluno ANEE inclusos nesta U.E.:

Deficiências atendidas:

1) Você já participou de palestras ou cursos que abordam o tema ANEE?

( ) Não ( ) Sim

2) Já participou de palestras ou curso sobre avaliação?
( ) Sim
( ) Não 
( ) As vezes

3) As práticas avaliativas utilizadas pelos professores em sua escola, visam as características peculiares de cada ANEE?

( ) $\operatorname{Sim}$

( ) Não

( ) As vezes

4) Como você classifica o preparo dos professores para trabalhar com o ANEE?

( ) Bom

( ) Ótimo

( ) Ruim

Por quê?

5) Como a equipe gestora desta escola compreende a avaliação escolar do aluno ANEE?

6) A equipe gestora propõe discussões pedagógicas a respeito da avaliação escolar do ANEE com o grupo de professores da escola? E com a comunidade escolar? 
7) Você quer ressaltar alguma observação que possa contribuir com um melhor desenvolvimento e aproveitamento para avaliação do ANEE?

OBRIGADA! 


\section{B - QUESTIONÁRIO PROFESSORES}

\section{UNIVERSIDADE DE BRASÍLIA}

\section{UNIVERSIDADE ABERTA DO BRASIL}

\section{CURSO DE ESPECIALIZAÇÃOEM DESENVOLVIMENTO HUMANO E EDUCAÇÃO INCLUSIVA}

\section{PESQUISA}

Venho solicitar-lhe que responda ao presente questionário, que se destina a realização de um trabalho de pesquisa, cujo tema: Avaliação do ANEE nas séries iniciais.

1- Que tipo de avaliação utiliza comumente?

( )formativa

( )classificatória

( )diagnóstica e formativa

( )

2- A avaliação do aproveitamento educacional do ANEE deve utilizar instrumentos e estratégias diferenciadas? Por quê?

3- Você utiliza os mesmos critérios na correção de atividades do ANEE e dos demais alunos?
( ) sim
( )não

4- $\mathrm{O}$ atendimento em sala de recursos e/ou apoio, em sua opinião, melhora o desempenho do ANEE em sala de aula? Como?

5- Quais os métodos de avaliação utilizados para o ANEE?

6- Qual a porcentagem de ANEE aprovados no ano de 2009 e 2010 ? 
7- Você elabora Adequação curricular para seu ANEE? Quanto tempo você precisa para escolher e/ou desenvolver a melhor estratégia para seu aluno?

8- Quantos ANEE são atendidos nessa escola?

9- $\overline{\text { Quando você recebe um ANEE procura se informar sobre as melhores estratégias de ensino }}$ para este aluno e sobre sua deficiência? Por quê?

10- Em sua opinião o que faltou e falta para um melhor desempenho nas estratégias de ensino aprendizagem para o ANEE que você atende? 


\section{C - ENTREVISTA PAIS}

UNIVERSIDADE DE BRASÍLIA

UNIVERSIDADE ABERTA DO BRASIL

ESPECIALIZAÇÃO EM DESENVOLVIMENTO HUMANO, EDUCAÇÃO E INCLUSÃO ESCOLAR

Venho solicitar aos pais ou responsável do ANEE da Escola Classe 07 de Planaltina que responda a seguinte entrevista que se destina a realização de um trabalho de pesquisa, cujo tema: AVALIAÇÃO DOS ANEE NAS SÉRIES INICIAIS.

Deficiência de seu (a) filho (a):

Série que ele cursa:

Possui adequação curricular?

1) Você acompanha as atividades que seu (a) filho (a) realiza na escola?

2) Você concorda que a avaliação de seu (a) filho (a) corresponde à necessidade educacional dele?

3) Você acredita que as práticas de avaliação utilizadas pelos professores da escola ajudam na melhor escolha das estratégias para educação de seu (a) filho (a)? Ou apenas são avaliações classificatórias que não respeitam a necessidade de seu (a) filho (a)?

4) Quando você expõe suas opiniões a respeito do desenvolvimento de seu (a) filho (a)? 
5) Como você avalia o desenvolvimento de seu (a) filho (a)?

Aspectos positivos

Aspectos negativos

Você deseja ressaltar algo para melhor aproveitamento das avaliações de seu (a) filho (a)?

OBRIGADA! 


\title{
ANEXOS
}

\section{A - CARTA DE APRESENTAÇÃO - ESCOLAS}

\author{
Universidade de Brasília - UnB \\ Instituto de Psicologia - IP \\ Departamento de Psicologia Escolar e do Desenvolvimento - PED \\ Programa de Pós-Graduação em Processos de Desenvolvimento Humano e Saúde PG-PDS \\ Curso de Especialização em Desenvolvimento Humano, Educação e Inclusão Escolar
}

\section{A Diretora}

Escola de Planaltina

De: Prof ${ }^{a}$. Dra. Diva Albuquerque Maciel

Coordenadora Geral do Curso de Especialização em Desenvolvimento Humano, Educação e Inclusão Escolar

\section{Assunto: Coleta de Dados para Monografia}

Senhora, Diretora,

A Universidade Aberta do Brasil - Universidade de Brasília está em processo de realização da $1^{\mathrm{a}}$ oferta do curso de Especialização em Desenvolvimento Humano, Educação e Inclusão Escolar, do qual seis dentre as 20 turmas ofertadas são de professores e educadores da rede pública do DF (pólos UAB-UNB de Santa Maria e Ceilândia e Formosa-GO). Finalizamos agora a $1^{\text {a }}$ fase do curso e estamos iniciando a Orientação de Monografia.

É requisito parcial para a conclusão do curso, a realização de um estudo empírico sobre tema acerca da inclusão no contexto escolar, cujas estratégias metodológicas podem 
envolver: entrevista e/ou questionários com o corpo docente, pais e outros; observação; e análise documental. Os instrumentos utilizados para a coleta de dados serão: questionário e/ou entrevista semi-estruturados; gravador; para o registro das observações a prancheta, caderno, caneta; para o registro das imagens a máquina fotográfica.

A realização desses trabalhos tem como objetivo a formação continuada dos professores/servidores da rede pública, subsidiando-os no desenvolvimento de uma prática pedagógica refletida e transformadora, tendo como consequiência uma educação inclusiva.

Informo que foi autorizado pela Secretaria de Educação por meio do Memorando $\mathrm{n}^{\circ}$ 497/2010 - EAPE - DEM datado de 09/11/2010, a realização das coletas de dados para as pesquisas na Rede Pública de Ensino do Distrito Federal.

Informações a respeito dessa autorização podem ser verificadas junto a Secretaria de Educação por meio dos telefones $\mathrm{n}^{\circ}$

O trabalho será realizado pela Professora/cursista Cíntia Rocha Ribeiro Damacena sob orientação, de Cleia Alves Nogueira cujo tema é: Avaliação do ANEE em séries iniciais possa ser desenvolvido na escola sob sua direção.

Desde já agradeço, colocando-me a disposição de Vossa Senhoria para maiores esclarecimentos nos telefones: 84769248 ou por meio do e-mail: msdamacena@ig.com.br

Atenciosamente,

\section{Diva Albuquerque Maciel}

Coordenadora Geral do Curso de Especialização em Desenvolvimento Humano, Educação e Inclusão Escolar 


\section{B - TERMO DE CONSENTIMENTO LIVRE E ESCLARECIDO - PROFESSOR}

Universidade de Brasília - UnB

Instituto de Psicologia - IP

Departamento de Psicologia Escolar e do Desenvolvimento - PED

Curso de Especialização em Desenvolvimento Humano, Educação e Inclusão Escolar

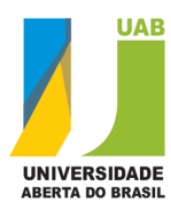

\section{TERMO DE CONSENTIMENTO LIVRE E ESCLARECIDO}

Senhores Professores,

Sou orientando do Curso de Especialização em Desenvolvimento Humano, Educação e Inclusão Escolar, realizado pelo Instituto de Psicologia por meio da Universidade Aberta do BrasilUniversidade de Brasília (UAB-UNB) e estou realizando um estudo sobre Este estudo poderá fornecer às instituições de ensino subsídios para o planejamento de atividades com vistas à promoção de condições favoráveis ao pleno desenvolvimento dos alunos em contextos inclusivos e, ainda, favorecer o processo de formação continuada dos professores nesse contexto de ensino.

Constam da pesquisa (RELACIONAR O QUE SERÁ FEITO: POR EXEMPLO, gravações em vídeo das situações cotidianas e rotineiras da escola, próprias da NEE, INCLUSAÕ, ETC e, ainda, entrevistas (gravadas em áudio) com os professores no intuito de...). Para isso, solicito sua autorização para participação no estudo.

Esclareço que a participação no estudo é voluntária. Você poderá deixar a pesquisa a qualquer momento que desejar e isso não acarretará qualquer prejuízo a você. Asseguro-lhe que sua identificação não será divulgada em hipótese alguma e que os dados obtidos serão mantidos em total sigilo, sendo analisados coletivamente. 
Caso tenha alguma dúvida sobre o estudo, o (a) senhor (a) poderá me contatar pelo telefone ou no endereço eletrônico . Se tiver interesse em conhecer os resultados desta pesquisa, por favor, indique um e-mail de contato.

Agradeço antecipadamente sua atenção e colaboração.

Respeitosamente,

Orientanda do ............UAB - UnB

Concorda em participar do estudo? ( ) Sim ( ) Não

Nome:

Assinatura:

E-mail (opcional): 